\title{
Актуальні питання забезпечення процесів планування оперативно-службової Державної прикордонної служби України
}

\author{
Артем Братко * 1 А Антон Дацков ${ }^{2}$ В; Віктор Березюк 3 А \\ А Національна академія Державної прикордонної служби України імені Богдана Хмельницького, м. Хмельницький, Україна
}

Received: November 5, 2021 | Revised: December 10, 2021 | Accepted: December 30, 2021

DOI: $10.33445 /$ sds.2021.11.6.5

\begin{abstract}
Анотація
В статті авторами проаналізовано та надано рекомендації, щодо процесів планування оперативно-службової діяльності Державної прикордонної служби України. Концептуальними і стратегічними документами держави визначено зміни щодо застосування сил прикордонного відомства в сучасних умовах. Існуючі форми оперативнослужбової діяльності набувають нового змісту. На Державну прикордонну службу України, як правоохоронний орган спеціального призначення, покладаються нові завдання щодо захисту державного кордону. У зв'язку з цим система управління Державної прикордонної служби України зазнає суттєвих змін. Розширюється коло завдань резервів Державної прикордонної служби України. Створюються мобільні, ефективні, оснащені сучасним озброєнням, військовою та спеціальною технікою прикордонні Спеціальні сили, що будуть забезпечувати своєчасне реагування на виклики та загрози прикордонній безпеці України, використовуючи раціонально наявний потенціал (спроможності). Постає нагальна необхідність сумісності системи планування з системою, яка прийнята у Збройних Силах України та НАТО на основі спроможностей. Запровадження в діяльність Державної прикордонної служби України планування оперативно-службової діяльності на основі спроможностей дасть змогу значно покращити якість планування, підвищити здатність Державної прикордонної служби України до виконання завдань в сфері забезпечення безпеки державного кордону. Виконання даних заходів, спільно з іншими складовими сектору безпеки та оборони, забезпечить активну участь України в реалізації Спільної безпекової та оборонної політики ЄС та співробітництві з НАТО для забезпечення виконання вимог набуття повноправного членства в Північно-Атлантичному Альянсі.
\end{abstract}

Ключові слова: спроможності, планування, документи, Державна прикордонна служба України.

\section{Постановка проблеми}

Національна безпека України передбачає захищеність державного суверенітету, територіальної цілісності, демократичного конституційного ладу та інших національних інтересів України від реальних та потенційних загроз [1]. Так, для забезпечення національної безпеки України розробляються відповідні нормативно-правові документи, які передбачають концептуальні засади та стратегічне планування.

Державна прикордонна служба України повинна здійснювати заходи планування оперативно-службової діяльності взаємодіючи з іншими складовими сектору безпеки та оборони відповідно до процедур і стандартів країн-членів НАТО. Перехід на відповідну методологію планування

\footnotetext{
1 * Corresponding author: к.військ.н., доцент, докторант, e-mail: bratkoav84@gmail.com, ORCID: 0000-0001-5503-3318

2 к.псих.н., професор кафедри, e-mail: datskovanton@gmail.com, ORCID: 0000-0001-7110-8666

${ }^{3}$ к.пед.н., доцент кафедри, e-mail: viktor.bereziuk@gmail.com, ORCID: 0000-0001-8565-5441
} 
відповідно до процедур і стандартів країнчленів НАТО має велике значення для підвищення

обороноздатності

держави. нашої

Аналіз останніх досліджень та публікацій

Питаннями організації та планування діяльності Збройних Сил України (далі - ЗСУ) та інших складових сектору безпеки та оборони присвячено низьку наукових робіт, зокрема [2-5]. У визначених наукових працях проводились дослідження щодо: стану та перспектив розвитку системи оборонного планування В ЗСУ; проблем розвитку спроможностей сил безпеки та оборони; стратегічного планування за підходами управління, орієнтованого на результат; стратегічного планування відповідно до процедур 3 урахуванням планування на основі спроможностей. Відповідно залишається невирішеним актуальним питанням процес планування оперативнослужбової діяльності Державної прикордонної служби України (далі - ДПСУ) на основі спроможностей.

\section{Постановка завдання}

Провести аналіз наявних керівних документів та нормативних актів та надати рекомендації щодо планування оперативно-

\begin{abstract}
службової діяльності Державної прикордонної служби України на основі спроможностей.
\end{abstract}

\section{Виклад основного матеріалу}

Правову основу державної політики у сферах національної безпеки і оборони становить Конституція України, яка визначає, що територія України в межах існуючого кордону $\epsilon$ цілісною та недоторканою, а оборона України, захист суверенітету, територіальної цілісності і недоторканості покладаються на Збройні Сили України. Забезпечення державної безпеки і захист державного кордону України покладаються на відповідні військові формування та правоохоронні органи держави, організація і порядок яких визначається законом. Важливим $\epsilon$ те, що Конституція України визначає стратегічний курс, а саме набуття повноправного членства України в Європейському Союзі та в Організації Північноатлантичного договору [6].

Таким чином, Конституція України визначила основні концептуальні засади для діяльності та подальшого розвитку складових сектору безпеки та оборони в цілому.

Наступним концептуальним документом $\epsilon$ закон України “Про національну безпеку України”, що визначає принципи та основи національної безпеки і оборони, цілі й основні засади державної політики, що гарантують суспільству і кожному громадянину захист від загроз.

Цим Законом визначено та розмежовано повноваження державних органів у сферах національної безпеки і оборони, створюється відповідна основа для інтеграційної політики та процедур органів державної влади, інших державних органів, функції яких стосуються національної безпеки і оборони, сил безпеки і оборони, визначається система командування, проведення контролю та координації операцій сил безпеки і оборони, запроваджується всеохоплюючий підхід до здійснення планування у сферах національної безпеки і оборони, забезпечуючи у такий спосіб демократичний цивільний контроль над органами та формуваннями сектору безпеки та оборони.

Передбачає захист суверенітету, територіальної цілісності та недоторканності. Визначено, що Державна прикордонна служба України є правоохоронним органом спеціального призначення, що реалізує державну політику у сфері безпеки державного кордону України та охорони суверенних прав України в її виключній (морській) економічній зоні [1]. 
Концепція розвитку сектору безпеки і оборони передбачає визначення шляхів формування національних безпекових та оборонних спроможностей, які дадуть змогу відновити територіальну цілісність України у межах міжнародно визнаного кордону України, гарантувати мирне майбутнє України як суверенної та незалежної, правової, демократичної соціальної держави, а також забезпечить створення національної системи реагування на виникнення кризових ситуації, своєчасне виявлення, запобігання й нейтралізацію зовнішніх і внутрішніх загроз національній безпеці, гарантування особистої безпеки, конституційних прав та свобод людини i громадянина, забезпечення кібернетичної безпеки, оперативне спільне реагування на виникнення кризових та надзвичайних ситуацій.

Реалізація досягатиметься шляхом:

- створення ефективної системи щодо управління сектором безпеки та оборони як цілісною функціональною системою;

- об'єднання оперативних спроможностей складових сектору безпеки та оборони для забезпечення своєчасного та адекватного реагування на кризові ситуації, що загрожують національній безпеці;

- постійного підтримання визначених сил безпеки та оборони в готовності до виконання відповідних завдань за призначенням;

- удосконалення комплексної системи планування у секторі безпеки і оборони, забезпечення раціонального використання державних ресурсів.

Основні зусилля 3 розвитку сектору безпеки і оборони зосереджуватимуться на поетапному та узгодженому нарощуванні оперативних спроможностей сил безпеки і оборони та рівня їх готовності до невідкладного реагування на виклики й загрози національній безпеці України [7].

Наступним концептуальним документом $\epsilon$ Річна національна програма під егідою Комісія Україна - НАТО на 2020 рік.

Державна прикордонна служба України повинна ефективно реалізовувати політику у сфері забезпечення безпеки державного кордону України.

Метою подальшого розвитку Державної прикордонної служби України $€$ зменшення загроз безпеці державного кордону України, забезпечення реалізації стратегічного курсу держави на набуття повноправного членства в Європейському Союзі та НАТО, посилення ролі Державної прикордонної служби України у протидії транскордонній і транснаціональній злочинності.

Створення мобільних, ефективних, оснащених сучасним озброєнням, військовою та спеціальною технікою прикордонних Спеціальних сил Державної прикордонної служби України, що забезпечують своєчасне реагування на воєнні загрози прикордонній безпеці України, раціонально використовуючи відповідний наявний потенціал (спроможності).

Продовжується робота щодо подальшої розбудови державного кордону та його інфраструктури за кращими європейськими зразками.

Система стратегічного планування повинна забезпечити ефективне виконання Державною прикордонною службою України завдань за призначенням.

Сформована інституційна спроможність для реалізації Державною прикордонною службою України відповідних заходів щодо стратегічного планування, яке досягається виконанням таких першочергових завдань:

а) упровадження автоматизованої системи забезпечення стратегічного планування та моніторингу виконання програмних документів (кінцевий термін виконання 2025 рік);

б) вивчення та застосування досвіду держав - членів НАТО для вдосконалення системи стратегічного планування у Державній прикордонній службі України (кінцевий термін виконання - 2025 рік).

Процес стратегічного планування в Державній прикордонній службі України здійснюється у взаємодії 3 іншими 
складовими сектору безпеки і оборони, що досягається виконанням таких пріоритетних завдань:

- розроблення та впровадження в Державній прикордонній службі України системи стратегічного планування за підходами управління, орієнтованого на результат (Result-Based-Management), $\quad 3$ урахуванням планування на основі спроможностей (Capability-Based-Planning) та бюджетного планування (кінцевий термін виконання - 2025рік) [8].

Стратегічне планування забезпечується виконанням вимог Стратегії Національної безпеки України, яка передбачає:

- забезпечення основних напрямів зовнішньополітичної

внутрішньополітичної діяльності держави для забезпечення ії національних інтересів і безпеки;

- посилення спроможностей Збройних Сил України, інших органів сектору безпеки i оборони;

- протидія тероризму, розповсюдженню зброї масового ураження, міжнародній злочинності, наркотичної торгівлі, торгівлі людьми, політичному та релігійному екстремізму, нелегальній міграції, кібернетичним загрозам, негативним наслідкам зміни клімату, а також у попередженні та подоланні наслідків надзвичайних ситуацій природного і техногенного характеру;

- підвищення ефективності державної політики у сферах захисту державного кордону України та охорони суверенних прав України в її виключній (морській) економічній зоні, міграції.

- ефективне стратегічне планування i кризовий менеджмент, зокрема впровадження універсальних протоколів реагування на кризові ситуації та відновлення з урахуванням рекомендацій НАТО [9].

Наступним документом $€$ «Стратегія інтегрованого управління кордонами на період до 2025 року».

Передбачає ефективне управління державним кордоном, що в свою чергу забезпечує безпеку держави, розвиток ії економіки і людський потенціал. Впровадження ефективної системи управління державним кордоном буде сприятиме транскордонному співробітництву, збільшенню доходів державного та місцевих бюджетів, спрощенню інших форм законного руху осіб та туризму, послуг та товарів. Водночас державні кордони повинні бути закриті для всіх видів незаконної діяльності, що загрожують стабільності держави.

Інтегроване управління кордонами - це скоординована діяльність компетентних державних органів України і військових формувань, що спрямована на створення i підтримання балансу між забезпеченням належного рівня прикордонної безпеки та збереженням відкритості державного кордону для забезпечення транскордонного співробітництва, а також для осіб, що подорожують.

Суб'єктами інтегрованого управління кордонами $є$ МЗС, МBC, Мінфін, Мінінфраструктури, Держприкордонслужба, ДМС, Держмитслужба, СБУ, Національна поліція, Держпродспоживслужба, Національна гвардія, Збройні Сили (Повітряні та Військово-Морські Сили), що взаємодіють на відомчому, міжвідомчому, державному і міжнародному рівнях щодо досягнення цілей державної політики у сфері інтегрованого управління кордонами.

Інші державні органи можуть залучатися до виконання окремих завдань в інтересах реалізації державної політики у сфері інтегрованого управління кордонами.

Стратегія інтегрованого управління кордонами спрямована на реалізацію євроінтеграційного курсу розвитку України, який сприятиме збереженню стабільності на державному та міжнародному вимірах.

Стратегія визначає основні напрями системного формування державної політики розвитку i ефективного управління державним кордоном до 2025 року. 
Метою Стратегії $\epsilon$ забезпечення розвитку зовнішньоекономічних зв'язків та міжнародної торгівлі, сприяння переміщенню осіб і товарів через державний кордон та належна його захищеність.

Стратегія спрямована на запровадження ефективних інструментів співпраці та координації на внутрішньовідомчому, міжвідомчому, міжнародному рівнях, а також з приватним сектором [10].

Основним документом планування у ДПсу $\epsilon$ “Основні напрями діяльності та подальшого розвитку Державної прикордонної служби України у 2021 році", які передбачають:

- підвищення ефективності реалізації державної політики у сфері безпеки державного кордону України;

- забезпечення подальшого розвитку інтегрованого управління кордонами;

- готовність до охорони тимчасово неконтрольованих ділянок державного кордону, нарощення спроможностей у складі сил оборони;

- зміцнення

патріотичного виховання персоналу, підвищення рівня довіри та позитивного іміджу прикордонників;

- розвиток матеріального та технічного забезпечення [11].

“Річний план основних заходів Адміністрації ДПСу" $\epsilon$ плануючим документом в ДПСУ.

Передбачає сукупність управлінських рішень у відповідних сферах діяльності суб'єкта планування у формі системи завдань і заходів, які необхідно здійснити в певній послідовності визначеними виконавцями у встановлені строки для досягнення конкретних цілей та індикаторів. Передбачає планування:

- загальних заходів;

- оперативно-службової діяльність 3 охорони державного кордону та виключної (морської) економічної зони, територіальних та внутрішніх вод України;

- бойової та мобілізаційна готовності, участі у заходах територіальної оборони;
- розвитку системи зв'язку та

інформаційно-телекомунікаційних систем;

- повсякденної діяльності, охорони пунктів дислокації органів та підрозділів ДПСУ;

- роботи з особовим складом ДПСУ;

- всебічне забезпечення оперативнослужбової діяльності;

- прикордонно-представницької роботи. Правового забезпечення. Міжнародного співробітництва [12].

Наступним документом 3 планування оперативно-службової діяльності $\epsilon$ “Порядок роботи органів управління Державної прикордонної служби України з підготовки до оперативно-службової діяльності в наступному календарному році або іншому періоді", який передбачає етапи підготовки до оперативно-службової діяльності.

На першому етапі:

- проводиться тематичний аналіз загроз та ризиків щодо обстановки на державному кордоні, прогнозування та розвитку їх на ділянках відповідальності органу (підрозділу) охорони державного кордону;

- визначається мета подальший дій, формуються основні завдання оперативнослужбової діяльності (у регіональному управлінні, органі охорони державного кордону, загоні морської охорони);

- проводяться оперативно-тактичні розрахунки, здійснюється аналіз можливості органу охорони державного кордону (у тому числі його підрозділів) щодо виконання завдань оперативно-службової діяльності у наступному році або іншому періоді, обраховуються потреби у ресурсах;

- визначаються потреби органів охорони державного кордону, загонів морської охорони у потребі залучення додаткових сил та засобів зі складу резервів Голови Державної прикордонної служби України й інших органів охорони державного кордону, загонів морської охорони;

- формуються розрахунки потреб в техніці, озброєнні, технічних засобах охорони державного кордону та інших матеріальних засобах, роботах і послугах, коштах на їх 
придбання (виконання) щодо забезпечення виконання завдань оперативно-службової діяльності у наступному календарному році або періоді.

На другому етапі планування оперативнослужбової діяльності проводиться:

- стратегічний аналіз ризиків в ході якого обов'язково здійснюється оцінка загроз (визначаються зовнішні та внутрішні чинники, які негативно впливають на сферу безпеки державного кордону), оцінка вразливості та визначається спроможність органів та підрозділів охорони державного кордону (аналізуються складові частини системи охорони державного кордону, а також чинники, що притягують загрозу), оцінюється вплив (визначаються наслідки реалізації загрози для сфери безпеки державного кордону, у тому числі наслідки, які впливають на пропуск через державний кордон осіб, транспортних засобів, вантажів, а також інших сфер національної безпеки України тощо), а також визначаються рівень ризиків та їх прогноз;

- враховуючи показники бюджету поточного періоду, здійснюється аналіз спроможності ДПСУ щодо реалізації

\section{Висновки}

Аналіз $\epsilon$ науково-методичною основою, який в подальшому може бути використаний під час надання пропозицій щодо визначення основних напрямів діяльності та подальшого розвитку Державної прикордонної служби України, а також враховано під час надання пропозицій щодо змісту проєкту Стратегії громадської безпеки та цивільного захисту України. Концептуальними і стратегічними документами держави визначено концептуальні зміни щодо застосування сил ДПСУ в сучасних умовах. Існуючі форми оперативно-службової діяльності набувають нового змісту.

На ДПСУ як правоохоронний орган спеціального призначення покладаються нові завдання щодо захисту державного кордону. Нового розвитку набувають дії сил ДПСУ під час покладених функцій;

- корегуються (за потреби) принципові підходи до здійснення оперативно-службової діяльності у наступному календарному році або іншому періоді, основні завдання оперативно-службової діяльності, порядок і способи їх реалізації, визначається порядок виконання завдань додатковими силами i засобами в інтересах регіональних управлінь (за потреби надсилається відповідне розпорядження до органів ДПСУ);

- формуються і надсилаються до органів ДПСУ попередні видатки на діяльність;

- враховуючи пропозиції органів ДПСу та фінансово-ресурсне забезпечення, розробляються відповідні документи 3 питань оперативно-службової діяльності у наступному календарному році або іншому періоді (директиви, накази за видами забезпечення тощо) та відправляються до органів ДПСУ;

- проводяться відповідні заходи 3 організації взаємодії, надання практичної допомоги та контролю підготовки до оперативно-службової діяльності в органах дПСУ [13].

реагування на кризові ситуації в тому числі воєнного характеру.

У зв'язку з цим система управління ДПСУ зазнає суттєвих змін. Розширюється коло завдань резервів ДПСУ. Створюються ефективні, мобільні, оснащені сучасним озброєнням, військовою і спеціальною технікою прикордонні Спеціальні сили ДПСУ, які будуть забезпечувати своєчасне реагування на воєнні загрози прикордонній безпеці України, раціонально використовуючи наявний потенціал (спроможності).

Сформована інституційна спроможність для реалізації ДПсу заходів зі стратегічного планування, що передбачає:

- упровадження автоматизованої системи забезпечення стратегічного планування та моніторингу виконання програмних 
документів;

- вивчення та застосування досвіду держав членів НАТО для вдосконалення системи стратегічного планування у ДПСУ.

Процес стратегічного планування в ДПСУ повинен здійснюватися у взаємодії з іншими складовими сектору безпеки і оборони, що передбачає:

- включення представників ДПСУ до складу міжвідомчих робочих груп для узгодженого планування стратегічних документів;

- розроблення та впровадження в ДПСУ системи стратегічного планування за підходами управління, орієнтованого на результат (Result-Based-Management), 3 урахуванням планування на основі спроможностей (Capability-Based-Planning) та бюджетного планування.

Запровадження в діяльність ДПСУ планування оперативно-службової діяльності на основі спроможностей дасть змогу значно покращити якість планування, підвищити здатність ДПСУ до виконання завдань в сфері забезпечення безпеки державного кордону. Виконання даних заходів, спільно з іншими складовими сектору безпеки та оборони, забезпечить активну участь України в реалізації Спільної безпекової та оборонної політики ЄC та співробітництві з НАТО для забезпечення виконання вимог набуття повноправного членства в Північно-Атлантичному Альянсі.

\section{Список використаних джерел}

1. Про національну безпеку України : Закон України від 21.06.2018 № 2469-VIII. Відомості Верховної Ради України. 2018, № 31, ст. 1.

2. Руснак І.С. та ін. Оборонне планування на основі спроможностей: особливості та перспективи впровадження. Наука i оборона. 2017. № 2. C. 3-10. DOI: 10.33099/2618-1614-2017-0-2-3-10.

3. Горбулін В. П. Розвиток оборонного планування як складової національної системи планування у сфері безпеки і оборони за умов наближення до процедур та стандартів НАТО : аналітична записка. Київ : НІСД, 2017. 17 с.

4. Буняк О. В., Бондарь Р. Г., Романюк І. М. Проблеми розвитку спроможностей сил оборони. Проблеми формування ефективної політики, системи планування і управління ресурсами в секторі оборони 3 використанням сучасних євроатлантичних підходів : матеріали міжнар. наук.-практ. конф., м. Київ, 24 бер. 2017 р. Київ : НУОУ, 2017. С. 16-19.

5. Романченко І. С., Богданович Ю. В., Дєнєжкін М. М., Крикун П. М. Стан і перспективи розвитку системи оборонного планування в Збройних Силах
України. Наука і оборона. 2017. № 1. С. 2530.

6. Конституція України : Відомості Верховної Ради України (BВP), 1996, № 30, ст. 141 URL: https://zakon.rada.gov.ua/laws/show/254\% D0\%BA/96-\%D0\%B2\%D1\%80\#Text (дата звернення: 12.07.2021).

7. Про рішення Ради національної безпеки і оборони України від 4 березня 2016 року “Про Концепцію розвитку сектору безпеки і оборони України" : Указ Президента України 14.03.2016 р. № 92/2016. URL: https://zakon.rada.gov.ua/laws/show/92/20 16\#Text (дата звернення: 10.09.2021).

8. Про Річну Національну програму під егідою Комісії Україна - НАТО на 2020 рік : Указ Президента України від 26.05.20 р. № 203/2020. URL: https://www.president.gov.ua/documents/2 032020-33861 (дата звернення: 08.09.2021).

9. Про рішення Ради національної безпеки і оборони України від 14 вересня 2020 року “Про Стратегію національної безпеки України" : Указ Президента України від 14.09.2020 p. № 392/2020. URL: https://zakon.rada.gov.ua/laws/show/392/2 020\#Text (дата звернення: 08.09.2021). 
10. Про схвалення Стратегії інтегрованого управління кордонами на період до 2025 року : Розпорядження Кабінету Міністрів України від 24.07.2019 р. № 687-p. URL: https://zakon.rada.gov.ua/laws/show/6872019-\%D1\%80\#Text (дата звернення: 25.10.2021).

11. Основні напрями діяльності та подальшого розвитку Державної прикордонної служби України у 2021 році. URL: $\quad$ https://dpsu.gov.ua/ua/-osnovninapryami-diyalnosti-ta-podalshogo-rozvitkuderzhavnoi-prikordonnoi-sluzhbi-ukraini/ (дата звернення: 27.09.2021).
12. Методичні рекомендації з планування в Державній прикордонній службі України : Наказ Адміністрації Державної прикордонної служби України від 11.11.20 р. № 115

13. Порядок роботи органів управління Державної прикордонної служби України з підготовки до оперативно-службової діяльності в наступному календарному році або іншому періоді : Наказ Міністерства внутрішніх справ України від 26.04.2018 р. № 350 Зареєстровано в Міністерстві юстиції за № 618/32070 від 23.05.2018 p.

\title{
Актуальные вопросы обеспечения процессов планирования оперативно-служебной Государственной пограничной службы Украины
}

\author{
Артем Братко * 1 А; Антон Дацков 2 А; Виктор Березюк 3 А \\ * Corresponding author: ${ }^{1}$ кандидат военных наук, доцент, докторант, e-mail: bratkoav84@gmail.com, ORCID: 0000-0001-5503-3318 \\ 2 кандидат психологических наук, профессор кафедры, e-mail: datskovanton@gmail.com, ORCID: 0000-0001-7110-8666 \\ ${ }^{3}$ кандидат педагогических наук, доцент кафедры, e-mail: viktor.bereziuk@gmail.com, ORCID: 0000-0001-8565-5441 \\ А Национальная академия Государственной пограничной службы Украины имени Богдана Хмельницкого, г. Хмельницкий, Украина
}

\section{Аннотация}

В статье проанализированы и даны рекомендации относительно процессов планирования оперативно-служебной деятельности Государственной пограничной службы Украины. Концептуальными и стратегическими документами государства определены изменения применения сил пограничного ведомства в современных условиях. Существующие формы оперативно-служебной деятельности приобретают новое содержание. На Государственную пограничную службу Украины, как правоохранительный орган специального назначения возлагаются новые задачи по защите государственной границы. В связи с этим система управления Государственной пограничной службы Украины претерпевает существенные изменения. Расширяется круг задач резервов Государственной пограничной службы Украины. Создаются мобильные, эффективные, оснащенные современным вооружением, военной и специальной техникой, пограничные Специальные силы, которые будут обеспечивать своевременное реагирование на вызовы и угрозы пограничной безопасности Украины, используя рационально имеющийся потенциал (способности). Возникает необходимость совместимости системы планирования с системой, принятой в Вооруженных Силах Украины и НАТО на основе возможностей. Введение в деятельность Государственной пограничной службы Украины планирования оперативно-служебной деятельности на основе способностей позволит значительно улучшить качество планирования, повысить способность Государственной пограничной службы Украины к выполнению задач в сфере обеспечения безопасности государственной границы. Выполнение данных мер, совместно с другими составляющими сектора безопасности и обороны, обеспечит активное участие Украины в реализации общей политики безопасности и обороны ЕС и сотрудничестве с НАТО для обеспечения выполнения требований полноправного членства в Северо-Атлантическом Альянсе. 
Ключевые слова: возможности, планирование, документы, Государственная пограничная служба Украины.

\title{
Current issues of ensuring the planning of operational and service activities of the State Border Guard Service of Ukraine
}

\author{
Artem Bratko * 1 A; Anton Datskov ${ }^{2}$; ;iktor Bereziuk ${ }^{3 \mathrm{~A}}$ \\ * Corresponding author: ${ }^{1}$ PhD in Military Sciences, Associate Professor, e-mail: bratkoav84@gmail.com, ORCID: 0000-0001-5503-3318 \\ 2 Ukraine, PhD in Psychology, e-mail: datskovanton@gmail.com, ORCID: 0000-0001-7110-8666 \\ ${ }^{3}$ PhD in Pedagogics, e-mail: viktor.bereziuk@gmail.com, ORCID: 0000-0001-8565-5441
}

A National Academy of the State Border Guard Service of Ukraine named after Bohdan Khmelnitskyi, Khmelnytskyi, Ukraine

\begin{abstract}
In the article the authors analyzed and provided recommendations on the processes of planning operational and service activities of the State Border Guard Service of Ukraine. Conceptual and strategic documents of the state define changes in the use of border guards in modern conditions. Existing forms of operational and service activities acquire a new meaning. The State Border Guard Service of Ukraine, as a law enforcement body of special purpose, is entrusted with new tasks to protect the state border. In this regard, the management system of the State Border Guard Service of Ukraine is undergoing significant changes. The range of tasks of the reserves of the State Border Guard Service of Ukraine is expanding. Effective, mobile, equipped with modern weapons, military and special equipment border special forces are being created, which will ensure timely response to military threats to Ukraine's border security, rationally using the available potential (capabilities). There is an urgent need for compatibility of the planning system with the system adopted in the Armed Forces of Ukraine and NATO on the basis of capabilities. The introduction of operational-service planning activities in the activities of the State Border Guard Service of Ukraine will significantly improve the quality of planning, increase the ability of the State Border Guard Service of Ukraine to perform tasks in the field of state border security. The implementation of these measures, together with other components of the security and defense sector, will ensure Ukraine's active participation in the implementation of the EU Common Security and Defense Policy and cooperation with NATO to ensure compliance with the requirements for full membership in the North Atlantic Alliance.
\end{abstract}

Keywords: capabilities, planning, guiding documents, State Border Guard Service of Ukraine.

\section{References}

1. Pro natsional'nu bezpeku Ukrayiny : Zakon Ukrayiny vid 21.06.2018 № 2469-VIII. Vidomosti Verkhovnoyi Rady Ukrayiny. 2018, № 31, st. 1. [in Ukrainian]

2. Rusnak I.S. ta in. (2017). Oboronne planuvannya na osnovi spromozhnostey: osoblyvosti ta perspektyvy vprovadzhennya. Nauka i oborona. 2017. № 2. S. 3-10. DOI :10.33099/2618-1614-2017-0-2-3-10. [in Ukrainian]

3. Horbulin V. P. Rozvytok oboronnoho planuvannya yak skladovoyi natsional'noyi systemy planuvannya u sferi bezpeky i oborony za umov nablyzhennya do protsedur ta standartiv NATO : analitychna zapyska. Kyiv : NISD, 2017. 17 s. [in Ukrainian]

4. Bunyak O. V., Bondar' R. H., Romanyuk I. M. Problemy rozvytku spromozhnostey syl oborony. Problemy formuvannya efektyvnoyi polityky, systemy planuvannya i upravlinnya resursamy $v$ sektori oborony $z$ vykorystannyam suchasnykh yevroatlantychnykh pidkhodiv : materialy mizhnar. nauk.-prakt. konf., m. Kyiv, 24 ber. 2017 r. Kyiv : NUOU, 2017. S.16-19. [in Ukrainian]

5. Romanchenko I. S., Bohdanovych YU. V., Dyenyezhkin M. M., Krykun P. M. (2017). Stan 
i perspektyvy rozvytku systemy oboronnoho planuvannya v Zbroynykh Sylakh Ukrayiny. Nauka i oborona. 2017. № 1. S. 25-30. [in Ukrainian]

6. Konstytutsiya Ukrayiny : Vidomosti Verkhovnoyi Rady Ukrayiny (VVR), 1996, № 30, st. 141 Available from: https://zakon.rada.gov.ua/laws/show/254\% D0\%BA/96-\%D0\%B2\%D1\%80\#Text (data zvernennya: 12.07.2021). [in Ukrainian]

7. Pro rishennya Rady natsional'noyi bezpeky i oborony Ukrayiny vid 4 bereznya 2016 roku "Pro Kontseptsiyu rozvytku sektoru bezpeky i oborony Ukrayiny" : Ukaz Prezydenta Ukrayiny 14.03.2016 r. № 92/2016. Available from: https://zakon.rada.gov.ua/laws/ show/92/2016\#Text (data zvernennya: 10.09.2021). [in Ukrainian]

8. Pro Richnu Natsional'nu prohramu pid ehidoyu Komisiyi Ukrayina - NATO na 2020 rik : Ukaz Prezydenta Ukrayiny vid 26.05.20 r. № 203/2020. Available from: https://www.president.gov.ua/documents/2 032020-33861 (data zvernennya: 08.09.2021). [in Ukrainian]

9. Pro rishennya Rady natsional'noyi bezpeky i oborony Ukrayiny vid 14 veresnya 2020 roku "Pro Stratehiyu natsional'noyi bezpeky Ukrayiny" : Ukaz Prezydenta Ukrayiny vid 14.09.2020 r. № 392/2020. Available from: https://zakon.rada.gov.ua/laws/show/392/2
020\#Text (data zvernennya: 08.09.2021). [in Ukrainian]

10. Pro skhvalennya Stratehiyi intehrovanoho upravlinnya kordonamy na period do 2025 roku : Rozporyadzhennya Kabinetu Ministriv Ukrayiny vid 24.07.2019 r. № 687-r. Available from: https://zakon.rada.gov.ua/laws/ show/687-2019-\%D1\%80\#Text (data zvernennya: 25.10.2021). [in Ukrainian]

11. Osnovni napryamy diyal'nosti ta podal'shoho rozvytku Derzhavnoyi prykordonnoyi sluzhby Ukrayiny u 2021 rotsi. Available from: https://dpsu.gov.ua/ua/osnovni-napryami-diyalnosti-ta-podalshogorozvitku-derzhavnoi-prikordonnoi-sluzhbiukraini/ (data zvernennya: 27.09.2021). [in Ukrainian]

12. Metodychni rekomendatsiyi z planuvannya $v$ Derzhavniy prykordonniy sluzhbi Ukrayiny : Nakaz Administratsiyi Derzhavnoyi prykordonnoyi sluzhby Ukrayiny vid 11.11.20 r. № 115 [in Ukrainian]

13. Poryadok roboty orhaniv upravlinnya Derzhavnoyi prykordonnoyi sluzhby Ukrayiny z pidhotovky do operatyvno-sluzhbovoyi diyal'nosti v nastupnomu kalendarnomu rotsi abo inshomu periodi : Nakaz Ministerstva vnutrishnikh sprav Ukrayiny vid 26.04.2018 r. № 350 Zareyestrovano $v$ Ministerstvi yustytsiyi za № 618/32070 vid 23.05.2018 r. [in Ukrainian] 